\title{
POLITICAL PRUDENGE IN SOME MEDIEVAL COMMENTARIES ON THE SIXTH BOOK OF THE NICOMACHEAN ETHICS
}

\author{
ROBERTO LAMBERTINI \\ Università degli studi di Macerata
}

The modern reader might well be surprised that John Buridan devotes so much of his commentary on the sixth book of the Nicomachean Ethics to questions about the unity of prudence. One question (q. I3) considers whether there are different prudences, each related to some specific moral virtue. A second question (q. I4) considers whether individual prudence, political prudence, and prudence regulating the household are all the same disposition. A third question (q. I5) examines the relationship between political prudence and legislative prudence, while a fourth (q. 17) concerns the relation between prudence, the moral sciences discussed in Aristotle's Ethics, Economics, and Politics, and those in books of laws and decreta. Where Aristotle himself devotes only one short passage to the unity of prudence ( $E \mathcal{N}$ I04Ib22-32), four out of Buridan's 22 questions on book 6 deal with a cluster of problems related to this topic.

A likely explanation lies in the tradition of commenting on the Nicomachean Ethics, ${ }^{1}$ especially at Paris. The few, entangled lines where Aristotle discusses the relationship between prudence and politics caused medieval interpreters so many problems that it became customary for the masters to raise questions at this point of their lectures. As often happens in the history of philosophy, the problems were not solved by so many interventions; on the contrary, questions tended to increase in number and length. The result of such discussions is an interpretation moving farther and farther from what we now recognize as the histori-

I would like to thank Bonnie Kent and István Bejczy for their most valuable help in finishing the present paper, that is dedicated to my parents.

${ }^{1}$ For an updated survey, see David A. Lines, Aristotle's Ethics in the Italian Renaissance (ca. I300-I650): The Universities and the Problem of Moral Education (Leiden, 2002), esp. 459 I. 
cal Aristotle's opinion, until it becomes almost independent. Of course, this does not make these discussions less interesting, at least in the eyes of medievalists.

The aim of this paper is to present some interpretations of the Aristotelian passage that in different ways helped to shape the commentary tradition. I shall focus in particular on the concept of political prudence, using it as a sort of litmus test of the development of the discussion.

\section{Aristotle's text}

Let us begin with the passage in the Nicomachean Ethics that served as a starting point for our commentators' discussions. According to the recensio recognita, the Latin translation that René-Antoine Gauthier thinks was the most popular among thirteenth- and fourteenth-century commentators, ${ }^{2}$ the passage reads:

Erit autem quaedam utique et hic architectonica. Est autem et politica et prudencia, idem quidem habitus, esse quidem non idem ipsis. Eius autem que circa civitatem, hec quidem ut architectonica prudencia legis positiva; hec autem ut singularia, commune habet nomen politica; ipsa autem activa et consiliativa. Sentencia enim operabilis; quare extrema.

Propter quod civiliter conversari hos solum dicunt. Soli enim operantur isti quemadmodum therotemne.

Videtur autem et prudencia maxime esse que circa ipsum et unum, et habet ipsa commune nomen prudencia. Illarum autem hec quidem ychonomia, hec autem legis posicio, hec autem politica; et huius hec quidem consiliativa, hec autem iudicativa. ${ }^{3}$

${ }^{2}$ René-Antoine Gauthier, "Introduction", in Aristotle, L'Ethique à Nicomaque, ed. René-Antoine Gauthier and Jean-Yves Jolif (Louvain-Paris, I970) I: I20-I3I; id., "Praefatio", in Aristotle, Ethica nicomachea, ed. René-Antoine Gauthier (Leiden-Brussels, I972-1974), CCXI-CCXLVII.

${ }_{3}$ Aristotle, Ethica nicomachea 6.8 (II4Ib23-II42aII), trans. Robert Grosseteste (recensio recognita), ed. Gauthier, p. 485; cf. also ibid., p. 26I (recensio pura). For an English translation see Aristotle, The Nicomachean Ethics, trans. James A.K. Thomson, rev. Hugh Tredennick, intr. Jonathan Barnes (London, 2004), I54-I55: "Political science and prudence are the same state of mind, but their essence is not the same. Prudence concerning the state has two aspects: one, which is controlling and directive, is legislative science; the other, which deals with particular circumstances, bears the name that properly belongs to both, that is, political science. This latter is practical and deliberative; for an enactement is a thing that can be done, and the last step 〈in a deliberative process $\rangle$. That is why only these persons are said to take part in politics, because they are 
At first sight, two main problems are at stake. On the one hand, Aristotle tries to explain why and in what sense politics and prudence are from different viewpoints the same and not the same; on the other hand, he discusses the relationship among different kinds of prudence. Grosseteste does not solve the problem by distinguishing between 'politics' as 'political science'-that is, a set of cognitions regarding a certain object (in this case, city-state government)-and 'prudence' as a virtuous disposition (habitus) of the soul. ${ }^{4}$ On the contrary, he translates the Greek as politica and embarks with Aristotle on a sort of classification of politics (and prudence too), which is made more complicated by the fact that in this classification two key terms, prudentia and politica, designate at the same time, broadly speaking, both a concept and one of its subordinate meanings. The classification is divided into two parts. In the first part, Aristotle focuses his attention on prudence concerning the city, distinguishing between a directive aspect, called legispositiva, and one dealing with particular matters, called politica, although the latter term, in ordinary usage, is also common to both aspects. After an effort to explain a way of speaking that does not include legislators among politici, Aristotle offers a more detailed classification encompassing individual, domestic, and political prudence. Politica is divided in turn into legislative and political, most probably in the sense already explained in the first classification. The latter is said to have a deliberative and a judicative part. In this passage, the Aristotelian text contains the ambiguous statement that prudence seems (videtur) to concern above all (maxime) the individual. It is not absolutely certain whether the Stagirite is here expressing his own opinion or merely reporting a common way of thinking and speaking. In the following and concluding lines, which I have not quoted, Aristotle presents and rejects the opinion that politicians cannot be regarded as prudent because a prudent man should confine himself to his own interests. ${ }^{5}$

the only ones that perform actions, like the artisans in 〈industry $\rangle$. Prudence is also especially identified with that form of it which is concerned with the self and the individual, and bears the name, prudence, that rightly belongs to all the forms, the others being called domestic, legislative and political science, and the last-named being devided into deliberative and juridical science".

${ }^{4}$ As happens in the English translation cited in the previous note. Cf. Aristotle, Nikomachische Ethik, trans. Eugen Rolfes, rev. Günter Bien (Hamburg, I985), I39, which translates the concepts with "Staatskunst" and "Klugheit", respectively; Aristotle, Etica nicomachea, trans. Marcello Zanatta (Milano, I986), 607, speaks of "politica" and "saggezza"; likewise Aristotle, Etica nicomachea, trans. Carlo Natali (Bari, I999), 239.

${ }^{5}$ I focussed my attention on this last part in "Individuelle und politische Klugheit 


\section{Conflicting interpretations: Eustratius and Albert the Great}

It is not surprising that medieval commentators had difficulties in interpreting these passages, and in particular in understanding what Aristotle meant by claiming that politics and prudence are at the same time identical and different. Henry of Friemar was well aware of the resulting disagreement among interpreters. In his commentary he wrote haec littera a diversis diversimode exponitur ${ }^{6}$ while John Buridan, some decades later, echoed this position, stressing that diversimode autem opinantes hanc auctoritatem diversimode exponunt. ${ }^{7}$

Medieval commentators on book 6 of the Nicomachean Ethics could often find some help in Eustratius's commentary, which Grosseteste had translated together with the Aristotelian text; ${ }^{8}$ but as far as this passage is concerned, the Greek bishop seems more interested in offering his own interpretation of the problem than in trying to reconstruct Aristotle's thought. His exegesis of the 'partial' identity of politics and prudence rests on the assumption that prudentia concerns first and foremost the individual. He maintains that they are the same in that both fulfill the task of bene consiliari and optimum homini operabilium coniectari, while they differ because politics concerns the city (civitas). According to Eustratius, it is possible to speak of prudentia in a general sense, but also, more specifically, of prudentia politica and prudentia moralis: the latter can be a synonym for prudentia without further qualification..$^{9}$ In the

in den mittelalterlichen Ethikkommentaren (von Albert bis Buridan)", in Individuum und Individualität im Mittelalter, ed. Jan A. Aertsen and Andreas Speer (Berlin-New York, I996), 464-478; a revised version of this paper in Italian is published on-line as "Est autem et politica et prudentia, idem quidem habitus: Appunti sul rapporto tra prudentia e politica in alcuni interpreti medievali del VI libro dell'Etica nicomachea (da Alberto Magno a Buridano)", Etica \& Politica / Ethics \& Politics 4 (2002), issue devoted to Individuo ed universale nelle dottrine morali del medio evo latino, ed. Guido Alliney and Luciano Cova (http://www.units.it/ etica/2002_2/index.html).

${ }^{6}$ Henry of Friemar, Sententia libri Ethicorum 6 q. I4, MS Erlangen, UB 212, f. $153^{\text {va }}$. For the transmission of this commentary see Clemens Stroick, Heinrich von Friemar: Leben, Werke, philosophisch-theologische Stellung in der Scholastik (Freiburg im Breisgau, 1954), esp. 53-59; Lines, Aristotle's Ethics, 466-467.

7 John Buridan, [Questiones] super libros Ethicorum 6 q. I4 (Paris, I5I3; repr. Frankfurt am Main, I968), f. $129^{\text {va }}$.

8 The most complete information on this collection of commentaries is contained in Mercken's introductions to his The Greek Commentaries on the Nicomachean Ethics of Aristotle in the Latin Translation of Robert Grosseteste, Bishop of Lincoln († 1253), ed. H. Paul F. Mercken (Leiden-Louvain, 1973-). Unfortunately, the commentaries on books 5 and 6 are still unedited. I will use MS Cambridge, Peterhouse ir6.

${ }_{9}$ Eustratius, In sextum Aristotelis moralium, MS Cambridge, Peterhouse iı6, f. I37 $7^{\mathrm{ra}}$ : 
following lines Eustratius explains that the difference between the two dispositions reflects a difference between the persons who can possess them. On the one hand, thanks to prudentia, the citizen (civis) reaches the good for himself in political life practicing political virtues, either obeying more prudent people or understanding the reasons for actions that lead to human perfection. On the other hand, prudentia politica allows the politicus to deal with other citizens and to take care of the whole city. Not surprisingly, Eustratius does not conceive of the sphere of moral prudence as completely separated from political life, but nevertheless understands political prudence as a disposition that not every citizen possesses. Moral prudence and political prudence should therefore be regarded as different dispositions, because they have different subiecta. ${ }^{10}$ These two dispositions can also be distinguished as a common prudence and a specific one, although the latter is called prudentia in ordinary language, and the former, concerning the common good, is called politica. ${ }^{11}$ Eustratius confirms this interpretation some lines later, commenting on the sentence videtur autem et prudencia maxime esse que circa ipsum et unum et habet ipsa commune nomen prudencia, that he understands this as an expression of Aristotle's thought and not as a common opinion he is merely reporting. According to his Greek interpreter, Aristotle is arguing here in favour of the idea that prudence in its proper sense concerns the individual and what is useful for him. If anything, what should be explained is why the Stagirite, while thinking that prudence is a disposition concerning the individual, insists on calling prudentia also dispositions concerning politics and the household. Eustratius answers

\footnotetext{
"Eadem quidem est politica et prudencia secundum quod utreque habent bene consiliari et optimum homini operabilium coniectari secundum ratiocinationem. Quia autem prudencia quidem secundum se ipsam prudentis est et coniectantis sibi ipsi optimum operabilium, politica autem communiter ciuitati optima coniectatur, propter hoc differunt ad inuicem ratione. Est enim et politica prudencia coniectativa, sed conferencium ciuitati communiter; non politica autem prudencia, sed moralis, proprie uni optima coniectat".

${ }^{10}$ Ibid.: "Quare ipsa quidem ciuis prudencia, illa autem politici, quia et ciuis quidem unus eorum qui in ciuitate utilium sibi ipsi coniectatiuus et sibi ipsi soli politicas uirtutes dirigere curam faciens, uel obediendo prudencioribus uel discendo et rationes habendo eorum que agit et operatur ducencium ad eam que secundum hominem perfectionem; politicus autem habens quidem et artem qualiter oportet cum ciuibus conuersari, curam agens autem et communiter omnis ciuitatis, ut utique in omnibus qui in ipsa dirigatur melius".

${ }^{11}$ Ibid.: "Diuidens prudentiam in specialem et communem et specialem quidem nominans communi nomine, politicam autem communem ut communiter de urbanitate coniectatiuam...".
} 
that such virtuous dispositions concern contingent and useful human actions, just as prudence does, but differ from prudence because their subiecta differ according to quantity (a household regards more than one person, politics even more people). According to this interpretation, it is possible to speak of a prudentia politica, ${ }^{12}$ a concept that does not surface as such in Aristotle's text.

The great scholar Gauthier considered this interpretation of Aristotle's meaning completely wrong ("un contresens"); ${ }^{13}$ nevertheless, for the first medieval commentators Eustratius was the most authoritative hermeneutic tool to which they had access. This does not imply, however, that they followed him blindly. On the contrary, Albert the Great, in his first commentary on the Ethics, alludes to Eustratius's interpretation several times, ${ }^{14}$ but chooses a different one. This is evident already at the level of literal exegesis: the more concise literal commentary by Albert ignores Eustratius's explanation of the 'partial' identity between prudence and refers the reader to his own question devoted to the subject. More importantly, Albert interprets the phrase videtur autem et prudencia maxime esse que circa ipsum et unum et habet ipsa commune nomen prudencia as the position of antiqui philosophi that Aristotle discusses but rejects. ${ }^{15}$ Albert's disagreement with Eustratius is evident in his questions. The question beginning Videtur, quod prudentia et politica sint idem habitus concludes that they are the same dispositions, differing only according to modus or ratio, because, Albert says, prudence belongs to reason in its directive function, while politics pertains to the level of execution. ${ }^{16}$ In the following question he adds that Aristotle's division of prudence does not proceed according to species, but according to different modes, so that prudentia as a common concept does not possess a generic unity, but

12 See above, n. 9 .

13 See the comments by Gauthier in Aristotle, L'Ethique à Nicomaque, p. 498.

14 See e.g. Albert the Great, Super Ethica 6.r I (549), ed. Wilhelm Kübel, Opera omnia (Münster, I95 ${ }^{-}-$) I4: 472. On Albert's ethical thought, see Jörn Müller, Natürliche Moral und philosophische Ethik bei Albertus Magnus (Münster, 200I) and, among the many and interesting contributions of this author, the article published in this volume.

15 Ibid., p. 471: "Primo ponit rationem et dicit, quod videtur quibusdam antiquis philosophis, quod prudentia maxime sit circa unum et proprium bonum..." (the italics in the edition highlight borrowings from Aristotle's text).

16 Ibid. (544), p. 467: "Dicendum, quod prudentia et politica sunt idem habitus secundum subiectum, sed differunt secundum modum sive secundum rationem, quia prudentia se magis tenet ex parte rationis dirigentis, quia est cum ratione eligibilium, sed politica se magis tenet ex parte operis; est enim quidam habitus eligibilium, prout sunt operabilia". 
a unity through analogy. ${ }^{17}$ The consequences of this different interpretation of the relation between politics and prudence emerge clearly in the following question, where Albert discusses the view quod prudentia sit circa ea que sunt communitatis. In fact, he does not even consider the possibility that prudentia could concern exclusively, or even primarily, the individual. Perfect prudence is able to direct actions both on the personal level and on the level of community. Although aware of the fact that there exist persons who seem to possess prudence in only one of these two spheres, the Dominican explains such cases as examples of merely imperfect prudence. ${ }^{18}$

The history of the reception of this Aristotelian passage in the Latin West begins, therefore, with a noticeable disagreement. The Greek commentator suggests that Aristotle here distinguishes between prudence in its most proper sense, as a virtue concerning the individual, and politics, as an aspect of prudence taken in a more general sense, namely the aspect concerned with the good of the community. He also thinks that this latter aspect is specific to a particular group of persons (politicians), while ordinary citizens content themselves with prudentia. A 'political prudence' does exist and belongs especially to the rulers. In his view, the partial identity between prudence and politics can be interpreted in a weaker way: that is, prudence in its more general sense encompasses more aspects, applied to different subjects of moral life, and one of them is politics. In Albert's view, on the other hand, prudence and politics regard the same wide spectrum of objects, differing only because the former is more connected to direction and the latter to execution. Albert refrains from considering individual prudence as

17 Ibid. (545), p. 468: "Dicendum, quod alia est divisio in species et alia in modos; divisio in species, quando dividitur genus per diversas differentias specificas, divisio autem in modos, quando sunt tantum diversae rationes in participatione unius communis, sicut analogum dividitur. Et talis divisio est hic, quia diversae partes prudentiae, quas assignat, non sunt diversae species nec differentes per substantiam habitus, sed per esse...".

${ }^{18}$ Ibid. (547), pp. 469-470: "Dicendum, quod prudentia, si simpliciter habeatur, dirigit in propriis et in his quae ad communitatem pertinent, quia non est perfecte prudens, qui se et alios regere nescit...; sed secundum quid est prudens, qui tantum scit se habere bene in propriis. Similiter etiam sunt aliqui qui bene se habent in regimine communitatis, sed in propriis nesciunt seipsos regere, et huius ratio est, vel quia contemnunt propria vel quia propriorum rationes sunt magis particulares et homo pluribus periculis subiacet quam civitas, et universale semper facilius est ad sciendum quam particulare. Tamen inter has duas prudentia principalior est illa quae ordinat bene in his quae sunt communitatis, quae est circa divinius bonum. Tamen etiam qui deficit in altero, non attingit optimum, quod est virtutis". 
prudence in its proper sense and rejects the idea of dividing prudence in general into species; on the contrary, he supports the idea that prudence simpliciter regards both the affairs of the individual and of the community. In all likelihood, then, it is not by chance that he does not employ the expression prudentia politica.

\section{Aquinas's solution}

Eustratius's interpretation was deemed to have greater success in the following years, in part because in his later paraphrasis of the Nicomachean Ethics Albert seems to abandon his own former interpretation, ${ }^{19}$ but especially because Thomas Aquinas embraces the opinion of the Greek commentator. In fact, Aquinas's Sententia libri Ethicorum adopts the distinction between prudentia and politica put forth by Eustratius: the former is right reason concerning good and evil actions of the individual, while the latter regards what Aquinas calls multitudo civilis..$^{20} \mathrm{He}$ speaks of an identity secundum substantiam and of a difference secundum rationem, in terms that seem to echo his teacher Albert, but interprets this difference as specific in a technical sense, that is, as a differentia specifica. ${ }^{21}$ Consistent with this view, Aquinas regards the sentence videtur autem et prudentia maxime esse que circa ipsum et unum as expressing Aristotle's own position. As a consequence, prudence applied to the individual retains the common name not only for linguistic reasons (that is, other

19 Albert the Great, Ethica 6.2.24, Opera omnia, ed. Stephanus C.A. Borgnet, $3^{8}$ vols. (Paris, I890-I899) 7: 44I: "Sunt autem politica et prudentia idem habitus: esse autem non est idem ipsis. Homo enim homo est et civis; et ideo conferens homini non perfecte confert nisi perfecte conferat et civi: et ideo habitus qui est de conferentibus homini, sub se continet habitum qui est de conferentibus civilitati... prudentia maxime videtur esse circa ea quae sunt homini per se solum existenti conferentia: haec enim est cui nomen prudentiae maxime deputatur. Aliarum autem prudentiarum quae sunt circa conferentia homini, non secundum quod est per se solus, sed secundum quod est domesticus vel civis, alia est denominatio...". As one can easily see, here Albert does not attribute this claim to "ancient philosophers", as he had done in his first commentary.

20 Thomas Aquinas, Sententia libri Ethicorum 6.7, Opera omnia iussu Leonis XIII edita (Rome, I882-) 47: 356: “... politica et prudentia sunt idem habitus secundum substantiam, quia utraque est recta ratio rerum agibilium circa humana bona vel mala, sed differunt secundum rationem; nam prudentia est recta ratio agibilium circa unius hominis bona vel mala, id est sui ipsius, politica autem circa bona vel mala totius multitudinis civilis".

${ }^{21}$ Ibid., p. 357: "omnia ergo de quibus hic fit mentio in tantum sunt species prudentiae in quantum...". 
aspects have their own, specific names, such as yconomia, legispositio, politica), but also because prudence maxime concerns individual matters. ${ }^{22}$ This does not imply, however, that Aquinas ignores the principle that the whole is superior to its parts; ${ }^{23}$ he acknowledges that political prudence is 'more principal' than prudence concerning the individual or the household and obviously rejects, together with Aristotle, the idea that people who devote themselves to the common good are not properly prudent. Nevertheless, he maintains that prudentia in its unqualified sense concerns the individual. ${ }^{24}$ The expression prudentia politica therefore finds its place in his exposition of Aristotle's text. ${ }^{25}$ In the Sententia libri Ethicorum Aquinas also introduces the concept pars that had already surfaced in Albert's commentary. This is reminiscent of works written before the complete translation of the Nicomachean Ethics, which often listed different 'parts' of the cardinal virtues. ${ }^{26}$

The treatment of prudentia in the Summa theologiae exploits in a systematic way the concept of parts of the virtue, allowing for potential, integral, and subjective parts of prudence. Leaving aside potential and integral parts, which would deserve a separate treatment, it is important to notice that Aquinas inserts politics among the subjective parts, explaining that prudence, taken in a general sense, has several species. ${ }^{27}$ Their classification follows a principle of binary division: the two main species

${ }^{22}$ Ibid.: "Dicit ergo primo quod, quamvis politica, tam legispositiva quam executiva, sit prudentia, tamen maxime videtur esse prudentia quae est circa unum tantum, scilicet circa se ipsum".

${ }^{23}$ Important studies of the problematic relationship between the individual good and the common good in late medieval political thought are Matthew S. Kempshall, "The Individual Good in Late Medieval Scholastic Political Thought-Nicomachean Ethics I.2 and IX.8", in Individuum und Individualität im Mittelalter, 493-510; id., The Common Good in Late Medieval Political Thought (Oxford, I999).

24 Thomas Aquinas, Sententia libri Ethicorum 6.7, p. 357: "Est etiam considerandum quod, quia totum principalius est parte et per consequens civitas quam domus et domus quam unus homo, oportet quod prudentia politica sit principalior quam yconomica et haec quam illa quae est sui ipsius directiva".

${ }^{25}$ Ibid.: “... quaedam vero est politica, id est prudentia exsequendi leges".

${ }^{26}$ Ibid.: "aliae partes prudentiae". Cf. Odon Lottin, Psychologie et morale aux XIIe et XIIIe siècles (Louvain-Gembloux, I942-1960) 3: 255-278. I focussed my attention on such issues from the point of view of the sources of De regimine principum in my "Tra etica e politica: La prudentia del principe nel De regimine di Egidio Romano", Documenti e studi sulla tradizione filosofica medievale 3 (1992), esp. I09-126.

27 Thomas Aquinas, Summa theologiae II.II.47.II, Opera omnia 8: 359: "Unde necesse est quod et prudentiae differant specie secundum differentiam horum finium: ut scilicet una sit prudentia simpliciter dicta, quae ordinatur ad bonum proprium; alia autem oeconomica, quae ordinatur ad bonum commune domus vel familiae; et tertia politica, quae ordinatur ad bonum commune civitatis vel regni". 
differ because one concerns the individual, while the other regards a multitude; such a multitude can be gathered for a purpose limited in time, such as an army, or for a purpose that extends to a lifetime. If the second possibility is the case, then one can distinguish between the domestic and the political community. When applied to these different communities, prudence becomes in the first case prudentia oeconomica, in the second prudentia politica. The latter, in turn, can be regnativa, i.e., directive and peculiar to the ruler, or politica simpliciter, the kind of political prudence which is peculiar to subjects. ${ }^{28}$

One can easily see that Aquinas follows Eustratius in explaining the main difference between prudence and politics, although he applies the distinction between the virtue of the citizen and the virtue of the politician to a sub-species of prudentia politica. In his view, prudence concerning the individual does not denote a virtue belonging to the individual qua citizen, as Eustratius seemed to suggest, but rather a virtue of the individual qua individual. Thus it not surprising that Aquinas feels the need to discuss whether prudence concerning the individual's good and prudence concerning the common good are the same in species (Utrum prudentia quae est respectu boni proprii sit eadem specie cum ea quae se extendit ad bonum commune). ${ }^{29} \mathrm{His}$ answer - that prudence in its most general sense, but not in its specific sense, is identical with politics ${ }^{30}$ - seems to suggest that the connection between these two dispositions of the soul is a loose one. If one also considers the fact that according to Aquinas, the virtue of the 'citizen' is part of prudentia politica, then his position seems to come closer to the claim that the virtue of the good man and of the good citizen do not coincide. Aristotle himself in the Politics restricts

28 Ibid. II.II.48.I, pp. 365-366: "Partes autem subiectivae virtutis dicuntur species eius diversae. Et hoc modo partes prudentiae, secundum quod proprie sumuntur, sunt prudentia per quam aliquis regit seipsum, et prudentia per quam aliquis regit multitudinem, quae differunt specie, ut dictum est, et iterum prudentia quae est multitudinis regitiva dividitur in diversas species secundum diversas species multitudinis. Est autem quaedam multitudo adunata ad aliquod speciale negotium, sicut exercitus congregatur ad pugnandum: cuius regitiva est prudentia militaris. Quaedam vero multitudo est adunata ad totam vitam: sicut multitudo unius domus vel familiae, cuius regitiva est prudentia oeconomica; et multitudo unius civitatis vel regni, cuius quidem directiva est in principe regnativa, in subditis autem politica simpliciter dicta".

29 Ibid. II.II.47.I I, pp. 359-36o.

30 Ibid., p. 359: "Ad primum ergo dicendum quod Philosophus non intendit dicere quod politica sit idem secundum substantiam habitus cuilibet prudentiae: sed prudentiae quae ordinatur ad bonum commune. Quae quidem prudentia dicitur secundum communem rationem prudentiae, prout scilicet est quaedam recta ratio agibilium: dicitur autem politica secundum ordinem ad bonum commune". 
the validity of this claim to perverse forms of constitution. ${ }^{31}$ Moreover, Aquinas seems to draw a distinction in species between the prudence of the ruler and that of the ruled (although both are sub-species of prudentia politica, which is in itself a species of the genus prudentia).

As mentioned before, Aquinas's interpretation prevailed. It was adopted with some minor modifications by Giles of Rome in his De regimine principum, a book that not only claimed to provide princes with a 'mirror' updated to reflect the medieval reception of Aristotle's practical philosophy, ${ }^{32}$ but which also served as easier access to the Nicomachean Ethics for learned people. ${ }^{33}$ In the relevant passages Giles draws inspiration not from the binary division of q. 48, but directly from q. 50 of the Secunda secundae, ${ }^{34}$ stating plainly that prudentia can be divided into five parts: particularis (concerning the individual), oeconomica (concerning the government of one's family), regnativa et legum positiva (concerning the city or the kingdom and necessary in the ruler), politica sive civilis (concerning obedience to the laws and to the orders of the ruler), militaris (concerning obstacles - such as enemies - that must be removed). ${ }^{35}$ As often happens when a doctrine is transmitted to a wider audience, the simplification pushes the doctrine itself to its limits. In the De regimine principum, prudence possesses many species that Giles puts on the same level, and regnativa differs from politica as oeconomica does from militaris. This implies that there is a species of prudence specifically different from prudence concerning the individual and from the prudence which

31 This issue was usually discussed in commentaries on Aristotle; see Christoph Flüeler, Rezeption und Interpretation der Aristotelischen Politica im späten Mittelalter (Amsterdam-Philadelphia, I992), esp. I07, II6, I43, I44, I47, I50, I6I. For a recent and interesting discussion of this issue see also Marco Toste, "Virtue and the City: The Virtues of the Ruler and the Citizen in the Medieval Reception of Aristotle's Politics", in Princely Virtues in the Middle Ages, I200-I5Oo, ed. István P. Bejczy and Cary J. Nederman (Turnhout, forthcoming). I wish to thank the author who allowed me to read the text before publication.

32 Roberto Lambertini, "Il filosofo, il principe e la virtù: Note sulla ricezione e l'uso dell'Etica Nicomachea nel De regimine principum di Egidio Romano", in Documenti e studi sulla tradizione filosofica medievale 2 (I99I), 239-279; id., "The Prince in the Mirror of Philosophy: About the Use of Aristotle in Giles of Rome's De regimine principum", in Les philosophies morales et politiques au moyen âge / Moral and Political Philosophies in the Middle Ages, ed. B. Carlos Bazán, Eduardo Andújar, and Léonard G. Sbrocchi (New York etc., I995), I522-I534.

33 See e.g. Charles F. Briggs, Giles of Rome's De regimine principum: Reading and Writing Politics at Court and University, c. I275 - c. 1525 (Cambridge, I999).

34 Thomas Aquinas, Summa theologiae II.II.5o, pp. 374-377.

35 Giles of Rome, De regimine principum 3.3.I (Rome, ı6o7; repr. Aalen, I967), 556-558. 
regulates the actions of the ruler, namely 'political prudence': a consequence that fits perfectly into the absolutistic tendency of the whole work. ${ }^{36}$

Thanks to Giles's mediating role, Aquinas's interpretation not only reached a wider public, it also influenced deeply the discussion at the Arts Faculty in Paris in the last decades of the thirteenth century. Question commentaries of the period have been the object of intense study since Grabmann's times because of their purported 'Averroism'. Their investigation contributed a lot to our reconstruction of an ethics of the Parisian Arts Masters ${ }^{37}$ Setting aside questions about the broader influence of Aquinas on the Arts masters, we can observe that their approach to problems concerning the relationship between politics and prudence, if not always their solutions, is much indebted to Aquinas's last works. The question at stake is whether the different species of prudentia constitute a unity or not, and the title of the question sometimes even reproduces the wording in the Summa theologiae. This is the case, e. g., for the commentary transmitted by MS Erlangen, Universitätsbibliothek 213, containing the question utrum eadem sit prudentia que est respectu boni proprii et que respectu boni alieni sive communis boni, which solves the problem by adopting Aquinas's solution. ${ }^{38}$ The

${ }^{36}$ Ibid., p. 557: "Quarta species prudentiae dicitur esse politica siue ciuilis. Nam sicut in principiante requiritur excellens prudentia qua sciat alios regere, sic in quolibet ciue requiritur prudentia aliqualis qua noscat adimplere leges et mandata principantis ... Differt autem haec prudentia a prudentia particulari, quam collocauimus in prima specie. Nam aliud est quod sciat se regere ut est aliquid in se, et aliud ut est subiectus principis".

37 To mention only some recent contributions: Georg Wieland, "The Perfection of Man: On the Cause, Mutability, and Permanence of Human Happiness in I3th Century Commentaries on the Ethica nicomachea (EN)", in Il commento filosofico nell'Occidente latino (secoli XIII-XV), ed. Gianfranco Fioravanti, Claudio Leonardi, and Stefano Perfetti (Turnhout, 2002), 359-377; Luca Bianchi, "Felicità intellettuale, ascetismo e arabismo: Nota sul De summo bono di Boezio di Dacia", in Le felicità nel medioevo, ed. Maria Bettetini and Francesco D. Paparella (Louvain-la-Neuve, 2005), I3-34; Iacopo Costa, "La dottrina della felicità nel 'Commento del Vaticano' all'Etica nicomachea", ibid. 325-353; id., "Il commento all'Etica nicomachea di Radulfo Brito: Edizione critica del testo con uno studio critico, storico e dottrinale" (Ph.D. diss. Università degli Studi di Salerno/Université de Paris IV-Sorbonne, 2007). See also Costa's contribution to this volume.

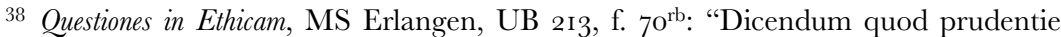
communiter accepte diuerse sunt species quarum una dicitur appropriato nomine prudentia, alia yconomica et $\langle$ alia $\rangle$ politica et illius politice alia est regnatiua siue legispositiua et alia appropriato nomine dicitur politica. Diuersitas autem istorum habituum sic patet, quia diuersitas habituum accipitur a diuersitate actuum seu obiectorum, non secundum quamcumque diuersificationem obiectorum, sed secundum formalem, 
commentary attributed to Radulphus Brito raises the question Utrum prudentia et politica sint idem and answers that this virtue in its general sense is divided into different species. ${ }^{39}$ Only Giles of Orléans prefers a solution closer to Albert's, stating that the unity of prudence should be explained in terms of analogy, not in terms of genus. ${ }^{40}$

\section{Henry of Friemar and the critical reaction to Aquinas's solution}

As I have shown elsewhere, ${ }^{41}$ disputed and quodlibetal questions from the end of the thirteenth century and the first decades of fourteenth bear witness to a certain unease towards the solution championed by Aquinas. While most authors adopt the idea of a distinction between different prudences, and coherently make use of the concept of prudentia politica, they have trouble accepting that such 'sub-prudences' should be distinguished as 'species', in part because this seems to imply that one of such species can exist without another. Among the critical reactions,

inquantum sunt obiecta, ut dicitur secundo De anima. Modo obiecta istorum habituum specie distinguuntur, ergo et ipsi habitus quia obiectum istorum habituum... est bonum humanum; modo aliud est bonum unius hominis et aliud familie et aliud ciuitatis; in diuersis enim ista bona consistunt et ideo obiecta istorum specie differunt formaliter, ideo et habitus. Unde prudentia est habitus uel recta ratio quo quis bene consiliatur de bonis suis(?)...".

${ }^{39}$ Radulphus Brito, Questiones in Ethicam, MS Vatican City, BAV Vat. lat. 832, f. $36^{\text {ra: }}$ "Dico ad questionem quod prudentia accipitur in communi uel proprie et stricte; si accipiatur in communi sic sunt eius tres partes, scilicet monostica, yconomica et politica. Si accipiatur proprie et stricte sic distincta est a politica et yconomica, cuius ratio est quod illi habitus sunt distincti quorum sunt distincta obiecta. Sed monostice, cui appropriatur nomen prudencie, et yconomice et politice sunt diuersa obiecta, quia obiectum monostice est bonum unius secundum se et prudentia monostica est recta ratio in operationibus unius hominis..."; for the attribution to Radulphus, see now Iacopo Costa, "Il commento all'Etica nicomachea di Radulfo Brito". For similar texts in related commentaries see René-Antoine Gauthier, "Trois commentaires 'averroïstes' sur l'Éthique à Nicomaque", Archives d'histoire doctrinale et littéraire du moyen âge I6 (I947I948), I89-213.

${ }^{40}$ Giles of Orléans, Questiones in Ethicam, MS Paris, BnF lat. I6089, f. $22 \mathrm{I}^{\mathrm{rb}}$ : "Unde notandum quod prudentia non est una secundum speciem et formam sed secundum analogiam et proportionem; est enim una sicut scientia; dicitur autem una scientia non quia sit unius obiecti secundum speciem et formam, sed quia est unius obiecti secundum attributionem sicut patet de prima philosophia que considerat ens secundum quod ens quod non est unum nisi secundum analogiam et sicut dicitur scientia una ita et prudentia dicitur una; bonum autem hominis scilicet secundum quod est pars ciuitatis ordinatur ad unum sicut ad ultimam hominis felicitatem".

${ }^{41}$ Roberto Lambertini, "Political Quodlibeta", in Theological Quodlibeta in the Middle Ages: The Thirteenth Century, ed. Christopher Schabel (Leiden, 2006), 441-444. 
Godfrey of Fontaines's disputed question, Utrum prudentia sit una, was especially influential. ${ }^{42}$

Commentaries on the Nicomachean Ethics are also involved in this development. Henry of Friemar's work, which includes both literal commentary and questions, is a telling example. The Augustinian friar seems so eager to address the problem that he even anticipates the discussion with respect to Albert or Aquinas. As already indicated, the issue was clearly related to the text contained in chapter 6.6 of the Ethics (according to the division of the revised version of the Liber Ethicorum). In the preceding chapter, however, claiming that the virtue of sapientia occupies the highest position among the intellectual virtues, Aristotle had rejected its identification with prudence and with politics, claiming that in this case there would be more than one sapientia. ${ }^{43}$ For a master aware of debates about the unity of prudence, this passage (which seems to imply that there are many 'prudences') provides a good opportunity to raise the issue and discuss it; so Henry inserts here a long and detailed quaestio bearing the title utrum prudentia que dirigit bonum unius sit eadem specie cum ea que dirigit bonum yconomicum uel civile. He feels it necessary to prove at the outset that prudentia concerning the individual good, called here prudentia monastica, is in itself one. The need to restate the unity of the prudence with respect to the various aspects of individual moral life could also be related to the tendency, discussed and rejected in authors such as Godfrey of Fontaines, to think that each moral virtue can possess its own prudence. ${ }^{44}$ After dismissing the idea that there can exist a specific prudence for each virtue, Henry is

\footnotetext{
42 Godfrey of Fontaines, Quaestiones ordinariae 3, in Le quodlibet XV et trois questions ordinaires de Godefroid de Fontaines, ed. Odon Lottin (Louvain, I937), I19-138. On Godfrey's political thought see Kempshall, The Common Good, 204-263; on prudence in particular: ibid., 234, 257.

43 Aristotle, Ethica nicomachea 6.6 (I I4Ia25-31), trans. Robert Grosseteste (recensio recognita), p. 484: "Circa se ipsum enim singula quidem bene speculans diceretur utique esse prudens et huic concederent ipsa. Propter quod et bestiarum quasdam prudentes aiunt esse quecumque circa ipsarum vitam videntur potenciam habere provisivam. Manifestum autem utique erit quoniam non utique erit sapiencia et politica eadem. Si enim eam que circa utilia ipsis dicunt sapienciam, multe erunt sapiencie".

${ }^{44}$ See Godfrey of Fontaines, Quaestiones ordinariae 3, pp. I29-132 (suggesting that in a certain sense each moral virtue can have its own prudence but arguing that all these different prudences are unified); for the context see Odon Lottin, Psychologie et morale 4: 548-663; for Scotus's position see Stephen D. Dumont, "The Necessary Connection of Moral Virtue to Prudence According to John Duns Scotus-Revisited", Recherches de théologie ancienne et médiévale 50 (1988), I84-206; Bonnie Kent, Virtues of the Will: The Transformation of Ethics in the Late Thirteenth Century (Washington, 1995), esp. 193-195.
} 
confronted with the problem of the identity of monastica, yconomica, and civilis. It is not surprising that he presents contrarie opiniones on this issue. ${ }^{45}$ The first asserts that the aforementioned virtues differ by species, while the second claims exactly the opposite, that is, that they are specifically identical. Both opinions, according to Henry, allow for doubts. For example, a distinction by species seem to imply that the related moral virtues also differ, so that the temperance exercised by a man who runs the political community would be different from the temperance that regulates the actions of the head of a household. Henry finds this consequence contrary to experience. ${ }^{46}$ Moreover, recalling an argument put forward by Godfrey of Fontaines, ${ }^{47}$ Henry remarks that such a distinction between 'prudences' different by species implies that the new leader of a political community cannot have the prudence that a leader should, because virtue is acquired through experience, and nobody can have experience in ruling others before being in charge. ${ }^{48}$

45 Henry of Friemar, Sententia libri Ethicorum 6 q. I4, f. I5 $\mathrm{I}^{\mathrm{rb}}$ : "Secundo restat inquirendum utrum ista prudentia sit eadem specie cum prudentia yconomica uel etiam ciuili, circa quod sunt contrarie opiniones. Quidam enim dicunt quod iste prudentie differunt specie... Alii autem econtrario dicunt quod prudentia in hiis tribus est eiusdem speciei".

${ }^{46}$ Ibid., f. I5I $\mathrm{I}^{\mathrm{va}}$ : "Utraque autem istarum opinionum uidetur dubitabilis. Si enim dicatur secundum primam opinionem quod iste prudentie differant specie, cum quelibet virtus formam et rationem virtutis habeat a prudentia, oportet necessario quod virtutes morales secundum diuersitatem istarum specie differrent. Et ulterius cum quelibet virtus moralis connectatur prudentie ut infra declarabitur, oporteret secundo iuxta diuersitatem prudentiarum $\langle$ con $\rangle$ nectentium dare tres species virtutum moralium. Quod etiam rationi et experientie contradicit. Experitur enim quilibet in se ipso quod si $\langle$ de $\rangle$ vita monostica transferatur ad communitatem domesticam uel ciuilem, uel etiam de statu subiectionis ad statum presidentie et gubernacionis, quod easdem virtutes exercet quas et prius".

47 Godfrey of Fontaines, Quaestiones ordinariae 3, p. I36: "Si autem loquamur de subdito qui non est subditus sic propter suam indigentiam, sed propter convenientem ordinem reipublicae quod unus principaliter multis principetur, propter quod contingit quod subditus potest esse aequalis in prudentia et virtute cum principe, et talis secundum veritatem non est subditus, sed secundum legem, sed debet dici bonus vir, sic est dicendum quod non differunt realiter sive secundum magis et minus, sed solum ratione sive ex habitudine et ordine ad aliud... Constat enim quod, cum aliquis bonus vir princeps fit, nulla fit mutatio realis circa eius prudentiam vel virtutem sed in quantum ex electione vel institutione principis consequitur auctoritatem et potestatem super alios, potest uti sua prudentia et virtute aliter quam bonus vir, sicut patet in habente scientiam perfecte absque auctoritate docendi et in habente cum scientia huiusmodi auctoritatem".

${ }^{48}$ Henry of Friemar, Sententia libri Ethicorum 6 q. I4, f. I5 ${ }^{\text {va. }}$ "Preterea, si status presidentie requireret virtutes morales speciei differentes ab habitus in statu subiectionis, tunc cum aliquis statum regiminis assumeret aut virtutes illi statui debitas non 
Although persuaded that the second opinion is 'more probable', Henry admits that there are strong arguments in favour of the opposing view. In particular, he is well aware of the fact that Eustratius seems to have shared it. ${ }^{49}$ Therefore, in order to avoid contradicting such an authority, Henry embarks on an interpretation of Eustratius according to which the ends pursued by the individual, by the head of the household, and by the politician are coordinated and not different enough to justify, properly speaking, a difference in species. According to the Augustinian master, Eustratius must therefore have used the term 'species' in a general, not a technical sense. ${ }^{50}$ Among 'prudences', differences undoubtedly exist, but they concern secondary and instrumental aspects of the exercise of such a virtue. ${ }^{51}$ Moreover, Henry is ready to concede that political prudence requires a higher degree of virtue than individual prudence; this amounts to saying, however, that one should at most admit a difference according to perfection, not according to substance. Political, domestic, and individual prudence should therefore be regarded as potential, not subjective parts of prudence taken in its general sense. ${ }^{52}$ Concluding his treatment of the issue, Henry is ready to formulate some arguments in favour of the opinion he does not share,

haberet, eo quod per exercicium nullas virtutes acquirere potuit, aut si detur quod habeat virtutes prius acquisitas, tunc virtutes in statu presidentie et subiectionis secundum speciem differre non possunt".

49 Ibid.: "... et secundum hoc opinio secunda probabilior uidetur, licet et ipsa dubitabilis sit maxime propter Eustratium qui uidetur sentire quod iste prudentie differant specie".

${ }^{50}$ Ibid., f. I5 $^{\mathrm{I}}$ ": "Et ideo ad sustinendum tam Eustratium quam etiam opinionem secundam que sine preiudicio mihi uidetur probabilior prima uidetur rationabiliter posse dici quod si considerentur iste prudentie quantum ad eorum formale obiectum et quantum ad finem principaliter intentum a quibus principaliter specificatur iste habitus sic re vera prudentia... est unius speciei... Si uero considerentur quantum ad aliqua obiecta et quantum ad fines non principaliter intentos, sic, cum circa talia obiecta et in ordine ad tales fines iste prudentie secundum diuersas rationes dirigant et precipiant, potest dici quod differant quantum ad diversam rationem dirigendi et precipiendi, et istam differentiam large et improprie loquens Eustratius appellat differentiam specificam".

${ }^{51}$ Ibid.: "ista sunt quedam extrinseca et secundaria obiecta adminiculantia". This is most probably an echo of the solution of Godfrey of Fontaines, Quaestiones ordinariae 3, p. I34: “... multis indigent adminiculis instrumentis quae non requiruntur ad hoc quod homo se ipsum et in se et in ordine ad alios convenienter dirigat... ideo si prudentia ad illa comparetur, in ipsa diversitas secundum hoc invenitur".

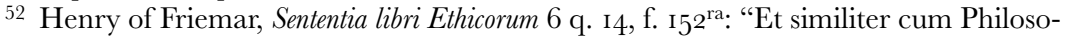
phus inferius distinguat diuersas partes uel species prudentie, non intendit loqui de differentia specifica secundum substantiam et speciem habitus, sed solum de diuersitate partium potentialium...". 
although he is not persuaded by them. He does this out of respect for the maiores who upheld that opinion and for those who want to follow them. ${ }^{53}$ This seems to me an allusion to Aquinas and his followers.

The problem of the unity of prudence surfaces again when Henry comments on the Aristotelian passage on which centers the whole discussion analyzed in this article. As we know, he informs the reader that there are diverging interpretations of the text. In the first place, he describes one possibility, according to which the identity between prudentia and politica means that politics is identical in substance with the kind of prudence that leads to common good, and differs only ratione. The words used to describe this opinion are strongly reminiscent of Aquinas in the Summa theologiae, although Henry's rendering does not take in account all aspects of Aquinas's position. ${ }^{54}$ Henry judges such a reading of Aristotle untenable because he thinks that it is not true in itself and does not correspond to Aristotle's intention. First, such an interpretation fails to account for the difference between politica understood as a science and prudentia, which is a virtue. Henry argues in fact that politica as a science, such as monastica - as he calls it - consists of scientific dispositions (habitus) of the soul regarding universal principles, while prudentia politica is more concerned with particulars and experience. ${ }^{55}$ Second, it is not faithful to Aristotle's intention as it emerges from the context, which is to distinguish between a prudence concerned with the good of the individual, and another one, called politica, ${ }^{56}$ that

${ }^{53}$ Ibid.: "Rationes prime opinionis solute sunt per iam dicta. Et quia prima opinio magnorum est, ideo, ne precludatur via ipsam sustinere volentibus, respondendum est ad rationes utriusque partis".

${ }^{54}$ Ibid., f. 153 va: "Quidam dicunt quod non intendit Philosophus quod politica sit idem habitus secundum substantiam cum qualibet prudentia, sed solum cum prudentia que dirigit bonum comune politicum; hec enim prudentia - ut dicunt - est idem habitus substantialiter cum politica, sed differt solum secundum esse et secundum rationem, quia ille habitus dicitur prudentia ut est recta ratio agibilium, sed dicitur politica inquantum ratiocinatur ad bonum commune". Cf. Thomas Aquinas, Summa theologiae II.II.47.II, p. 359: "Ad primum ergo dicendum quod Philosophus non intendit dicere quod politica sit idem secundum substantiam habitus cuilibet prudentiae: sed prudentiae quae ordinatur ad bonum commune. Quae quidem prudentia dicitur secundum communem rationem prudentiae, prout scilicet est quaedam recta ratio agibilium: dicitur autem politica secundum ordinem ad bonum commune".

${ }^{55}$ As a matter of fact, this first objection of Henry's seems to be connected to a particular meaning of prudentia politica, inspired by the definition of politica that Aristotle gives to distinguish it from legispositiva. However, he often uses prudentia politica in a different, broader meaning.

${ }^{56}$ Henry of Friemar, Sententia libri Ethicorum 6 q. I4, f. I53 va: "Sed ista expositio dupliciter uidetur deficere. Primo non uidetur vera in se: politica enim sicut et monas- 
leads to the common good. According to Henry's reconstruction, such difficulties gave rise to a different opinion, namely that prudence possesses a generic unity, as Eustratius suggests; ${ }^{57}$ but Henry does not share this opinion, either. He thinks that a distinction in different species applies not to virtues proper but only to the habitus scientifici regarding a theoretical knowledge concerning good and evil actions. As habitus scientifici, politica and yconomica do differ according to species. Different kinds of prudence differ, on the contrary, only as they pertain to a greater or smaller number of persons. ${ }^{58}$ Henry's next question-utrum legis positiua que in tertio politice dicitur regnatiua, politica et yconomica sint partes prudentie ${ }^{59}$ offers him the opportunity to emphasize the solution already put forward in the preceding discussion: such dispositions of the soul, which are subordinated to prudence, should be considered as potential parts of prudence. This does not exclude the view that politics occupies a higher position on the scale of perfection, because it concerns the common good and - in its legislative aspect - plays the leading role usually proper to the ruler. In this sense, prudentia politica is the most perfect potential part of prudence. ${ }^{60}$

tica importat quendam habitum scientificum quo uniuersales raciones agibilium scientifice speculamur. Constat autem quod talis habitus non possit esse idem substantialiter et realiter cum prudencia politica, tum quia ista est consideratiua agibilium magis principaliter et in particulari et per uiam experimenti, illa uero solum uniuersaliter et scientifice, tum etiam quia multi per doctrinam experimentalem habent prudentiam politicam qui tamen nihil de rationibus agibilium scientifice cognoscunt. Secundo quia non est secundum mentem Philosophi, quia Philosophus hic intendit distinguere notitiam agibilium in prudentiam simpliciter, que tantum dirigit bonum unius, et in politicam que considerat bonum multitudinis".

${ }^{57}$ Ibid.: "Et ideo dicunt alii quod prudentia et politica est idem habitus in genere quia conueniunt in aliqua apparentia quo (sic pro a quibus) accipitur communitas generis. Nam secundum Eustratium conueniunt in hoc quod est bene consiliari circa humana bona vel mala sed differunt secundum esse, id est secundum rationem formalem et speculatiuam quia prudentia est bene consiliatiua circa bona conferentia uni tantum, politica autem circa bona conferentia ciuitati et regno et quia hec bona secundum eos differunt secundum rationes eorum formales et specificas, ideo prudencia et politica important habitus substantialiter et specifice differentes". Strangely enough, Henry does not indicate that this position could also be traced back to Aquinas; the problem would deserve further investigation.

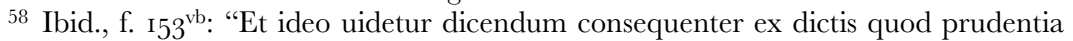
et politica sunt quidem idem habitus in genere ut dictum est, sed esse non est idem quia bonum humanum quod in ipsis intenditur multitudine differt et paucitate ut patet ex dictis".

${ }^{59}$ Ibid., f. I $54^{\text {ra: }}$ "Sed hic forte dubitaret aliquis utrum legispositiva que in tertio politice dicitur regnativa et politica et yconomica sint partes prudentiae in communi".

60 Ibid., f. I54 
The lengthy and somewhat repetitive treatment in Henry's commentary bears witness to a twofold development. By the beginning of the fourteenth century an interpretation of the Nicomachean Ethics prevailed that cannot conceive of prudence in its proper sense as a virtue concerned with the political community, as Aristotle probably intended. Properly speaking, prudence directs the actions of the individual towards his end. Thus it becomes customary to speak of a special kind of prudence, called prudentia politica, that is perceived as different from prudence in itself. The discussion concerns how to undertand this difference. Many thinkers are unsatisfied with an interpretation that would separate the aspects of prudence from one another, as if they would be in reality different things. They seem to think that in this way one could jeopardize the unity of moral life. The attempt to avoid such a danger is particularly clear in Henry of Friemar, who uses the concept of 'potential part' in order to stress the tight connection among different degrees of prudence. The key role attributed to prudence as an individual virtue is somewhat counterbalanced by emphasizing the preeminence of the part of prudence concerned with the common good.

\section{John Buridan}

Against this background, many aspects of John Buridan's commentary become more comprehensible. In q. I3 of book 6, utrum prudentia sit una tantum circa obiecta omnium virtutum moralium, he takes a stand against the growing tendency to dissolve the unity of prudence. ${ }^{61}$ This is even

loquendo non differunt formaliter et specifice quantum ad formam et speciem habitus qui sumitur ex obiecto formali et primario, sed solum differunt quantum ad modum dirigendi circa quedam secundaria obiecta que proprie diuersitatem specificam inducere non possunt ut patet ex dictis, ideo melius uidetur consequenter dictis tenendum quod isti habitus inquantum inportant habitum prudentie sic diuersimode denominatum et ad diuersos gradus perfectionis contractum sint partes potentiales ipsius prudentie in communi secundum quas quidem partes diuersus modus directionis in prudentia attenditur et etiam diuersus gradus perfectionis in ipsa acquiritur, secundum quod dirigit uel ad bonum humanum principaliter intentum in monastica yconomica et politica uel etiam prout dirigit ad quedam bona secundaria ordinata ad bona principaliter intenta. Utroque enim modo constat quod perfectior directio prudentie requiritur in politico quam in yconomico et in illo adhuc perfectior quam in monastico, quia bonum quanto communius tanto difficilius dirigitur, eo quod ad eius directionem plura consideranda concurrunt".

${ }^{61}$ For discussion of this issue see James J. Walsh, "Buridan on the Connection of the Virtues", Fournal of the History of Philosophy 24 (I986), 453-482. 
more interesting if one takes into account that Gerald of Odo, whose commentary on the Nicomachean Ethics Buridan knew well and used extensively, ${ }^{62}$ supported a somewhat different position. ${ }^{63}$ It is remarkable that Buridan, as Henry of Friemar before him, defends the unity of prudence against an argument which had been used also to argue in favour of a specific difference between prudentia monastica and prudentia politica: the difference among their respective objects. Buridan claims that different kinds of actions are all objects of prudence according to one formal ratio, which gives them a sort of unity. ${ }^{64}$

Question I4 tackles directly the issue at stake, asking Utrum prudentia monastica et prudentia ciuilis et prudentia oeconomica sint idem habitus uel diversi. After remarking that Aristotle confines himself to a puzzling statement (quoted at the beginning of this essay), and noting that the relevant passage is interpreted in different ways, Buridan introduces three opinions, which we have already considered, at least in part. The supporters of the first think that the identity of individual and political prudence (here called prudentia civilis) should be explained by the fact that both inhere in the same subject, that is, the practical intellect. Their difference is a specific one, so that different 'prudences' can be compared to sweetness and whiteness in milk. Other maintain the opposite, namely that prudence possesses a specific identity. When it comes to explaining why prudence and politics differ, although they are the same disposition of the soul, the supporters of this opinion divide into two groups. They all agree that 'prudences' are not 'different things'; some, however, maintain that they nevertheless differ according to species because they possess different rationes quidditativae; others think rather that the difference is only accidental. Trying to explain this second position, Buridan says that the very same habitus, or even the very same actus, can be regarded by extrinsic denomination as belonging to one prudence or to another. ${ }^{65}$ Here the modern reader recognizes the influence of the

${ }^{62}$ Id., "Some Relationships between Gerald Odo's and John Buridan's Commentaries on Aristotle's Ethics", Franciscan Studies 35 (1975), 237-275.

${ }^{63}$ On Gerald's ethics, see Bonnie Kent, "Aristotle and the Franciscans: Gerald Odonis' Commentary on the Nicomachean Ethics" (Ph.D. diss. Columbia University, New York, 1984).

${ }^{64}$ John Buridan, Super libros Ethicorum 6 q. I3, f. I29" ra-rb: "Ad primam dicendum est quod omnia operabilia humana sunt obiecta prudentie secundum unam rationem formalem".

${ }^{65}$ Ibid. 6 q. I4, f. I29 ${ }^{\text {va-vb }}$. Among many studies devoted to this work, see Gerhard Krieger, Der Begriff der praktischen Vernunft nach fohannes Buridanus (Münster, I986); bibliographical references in Lines, Aristotle's Ethics, 470-471. 
great ontological debates of the first half of the fourteenth century, even if it is not easy to identify with precision the supporters of the different positions. For example, the ratio quidditativa is strongly reminiscent of the Scotist tradition and, as a matter of fact, this term was used in a parallel passage by Gerald of Odo. ${ }^{66}$

Buridan is well aware that ontological discussions have heavily influenced this conflicting interpretation of Aristotle's theory of prudence, but he is also very critical in this respect, because he finds that such metaphysical subtleties are inappropriate in ethics. ${ }^{67} \mathrm{He}$ thinks it sufficient to establish that prudentia monastica, oeconomica, and politica are one and the same disposition of the soul, because the common and individual goods coincide. The distinction is possible only secundum rationem. ${ }^{68}$

If we keep in mind the foregoing discussion, Buridan's solution is not very original: identity in esse and distinction ratione is a position that Henry of Friemar already considered and rejected. Much more original is the fact that Buridan inserts his solution into a long discussion claiming that this identity holds only for persons who understand the preeminence of spiritual goods in comparison to material goods. Members of the lower class (vulgus), says Buridan, are interested only in material goods. For such people, then, individual prudence and prudence directing one towards the common good cannot be identical. On the level of the bona corporis and of the bona exteriora, individual prudence and political prudence do not necessarily coincide; maybe they necessarily conflict. Concluding this excursus Buridan remarks that the mistake of such a position does not consist in conceiving of prudence as essentially

66 Gerald of Odo, Sententia et expositio cum questionibus... super libros Ethicorum 6 lectio

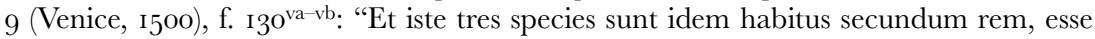
tamen formale earum seu ratio formalis et quidditatiua earum non est eadem. Quod patet quia actus earum formales perficiunt distincta formaliter, homo enim et ciuis subditus et princeps et iconomus sunt distincta formaliter secundum rationes suas, ratio enim hominis est absoluta, alie vero sunt relatiue que nihilominus distinguuntur quia sunt ad diuersos terminos".

${ }^{67}$ John Buridan, Super libros Ethicorum 6 q. I4, f. I29"v: "Hec autem que dicta sunt in hiis opinionibus forte magis speculabilia sunt quam pertineant ad istam scientiam; sunt etiam multum generalia; sicut autem dicitur secundo huius sermones quidem universales inaniores sunt, particulares vero veriores. Idcirco magis particulariter oportet de hiis perscrutari".

68 Ibid., f. $\mathrm{I}_{30} \mathrm{O}^{\mathrm{ra}}$ : “... propter quod manifestum est quod iste prudentie idem habitus sunt et non alius secundum rem: illo enim habitu et illa operatione quo vel qua aliis procuramus bona, eodem habitu et eadem operatione nobis bonum virtutis acquirimus. "Esse tamen non idem ipsis - ut dicit Aristoteles - id est ille habitus idem existens secundum rem diuersificari potest secundum rationem". 
devoted to one's own good, but in the fact that it focusses on the wrong kind of goods: material goods do not allow for a compatibility between the interests of the individual and the common good. ${ }^{69}$

From this point of view, Buridan's defence of the unity of prudence appears to reflect social prejudice, although it is most likely that vulgus has a moral rather than a sociological connotation. This interpretation can be confirmed by Buridan's treatment of the following question, which had also been raised by Henry of Friemar: utrum prudentia politica et prudentia legipositiva sint idem habitus. In this context, where prudentia politica signifies precisely an aspect of political prudence that can be distinguished from legispositiva, a question arises about the relationship between the ruler and the subjects. Buridan refuses to consider them as essentially different, arguing that if the opposite were true, then losing or acquiring power would affect the virtue of a human being. Relying on a lengthy quotation from Seneca, Buridan rejects as untenable such a conclusion. ${ }^{70}$ The very existence of doctores moralium such as Seneca and Cicero, who taught princes how to legislate and taught their subjects as well, shows, according to the Parisian master, the unity of prudence. ${ }^{71}$ Princes and subjects, shoemakers and sailors, the rich and the poor, all share the same virtue. ${ }^{72}$ The answer could be different only if 'prudence' meant the ability to perform external actions that are proper to some social or political position. Only if taken in this sense would the prudence of the ruler not be the same as the prudence of his subjects. $^{73}$

69 Ibid.: "Hec autem opinio in hoc verum assumit quod prudentia monostica que est vere et simpliciter prudentia consistit in bene consiliari posse et operari ad acquirenda sibipsi bona, sed errat in hoc, quod credat bona corporis et exteriora esse bona simpliciter et optima; prudens igitur simpliciter non nititur sibi diuitias acquirere".

70 Ibid. q. I5, f. I30 va: "Item si alia esset prudentia legislatoris et subditi, sequeretur quod fortuna de prudente faceret imprudentem et e converso; consequens est falsum, unde Seneca ad Lucillium epistula subinde dicit 'sapiens quidem, id est prudens, vincit virtute fortunam"”. On Seneca's importance for Buridan, see James J. Walsh, "Buridan and Seneca", Fournal of the History of Ideas 27 (ig66), 23-40.

71 Ibid. f. I3 $\mathrm{O}^{\mathrm{vb}}$ : "Iterum hoc manifeste potest apparere si aspexerimus ad antiquos patres, Aristoteles, Senecam, Tullium et ceteros moralium doctores, qui et principes et subditos prudenter docuerunt et principum consules fuerunt ad ponendum leges, quod non fuisset si non habuissent prudentiam hanc et aliam".

72 Ibid.: "Cum ergo diximus eandem esse prudentiam principis et subditi et cuiuscumque viri locuti sumus de prudentia simpliciter secundum quam habens dicitur bonus homo, sic scilicet intelligendo quod Sortes eadem prudentia erit bonus homo si fuerit princeps et si fuerit subditus et si dives et si pauper et si coriarius et si nauta et si carpentator et universaliter ad quemcumque statum pervenerit sed bonum".

73 Ibid., f. I $3^{\mathrm{ra}}$. 
The fourth and last question devoted by Buridan to this cluster of problems bears the title utrum prudentia sit idem habitus cum scientia morali tradita in libro ethicorum, politicorum et economicorum et etiam in libris legum et decretorum. ${ }^{74}$ Here Buridan discusses in detail a distinction that already emerged in Aquinas's and in Henry of Friemar's commentaries, ${ }^{75}$ namely the distinction between politica as a habitus scientificus (a set of cognitions) and politica as a prudentia that is not a mere knowledge concerning action, but a moral disposition of the soul. In the first place, Buridan rejects a solution according to which the difference between science and prudence can be reduced to the circumstance that habitus scientifici concern the universal, prudence, on the contrary, the singular. In his opinion, prudence does consist of what he calls universal propositions: their difference from the propositions proper to metaphysics or physics does not consist in their universality or lack of it, but in in their capacity to guide our actions. Prudence contains therefore a set of propositions, be they in the form of self-evident first principles or conclusions drawn from those principles. This position allows him to maintain that the content of the books of the scientia moralis does not differ essentially from prudence. ${ }^{76}$ In this way, Buridan stresses again the unity of prudence, also with respect to knowledge concerning moral action; yet at the same time he implicitly raises the question of wicked persons who know moral principles perfectly but do not act correctly. However, whether Buridan can be regarded as an 'ethical intellectualist' is a problem beyond the limits of the present paper. ${ }^{77}$

74 Ibid. q. I7, ff. $132^{\text {va }-} \mathrm{I} 33^{\mathrm{va}}$.

75 Thomas Aquinas, Sententia libri Ethicorum 6.7, p. 357: “... omnia ergo de quibus hic fit mentio in tantum sunt species prudentiae in quantum non in ratione sola consistunt, sed habent aliquid in appetitu; in quantum enim sunt in sola ratione, dicuntur quedam scientiae practicae, scilicet ethica, yconomica et politica".

76 John Buridan, Super libros Ethicorum 6 q. I7, f. I33"va: "videtur mihi quod habitus acquisitus ex doctrina librorum legum, decretorum et universaliter librorum moralium pertinet ad prudentiam, ita quod prudentia si sit perfecta continet in se habitum illum vel consimilem tanquam partem quandam ipsius, quoniam prudentia non est alius habitus quam secundum quem scimus quid et quomodo sit agendum ad bene vivendum et feliciter...".

77 Ibid.: “... nulli praui sciunt conclusiones ymo neque principia illorum librorum, licet enim bene sciant quid in illis libris scriptum sit et quid preceptum et quid prohibitum, tamen neque conclusionibus neque principiis neque huiusmodi preceptis nec prohibitionibusacquiescunt secundum mentem interiorem". On the problem of ethical intellectualism see recently István Bejczy, "Ethique et connaissance au moyen âge: La vertu entre intellectualisme et volontarisme", in Etica e conoscenza nel XIII e XIV secolo, ed. Irene Zavattero (Arezzo, 20o6), 9-13. 


\section{Conclusion}

Looking back over the development described in this brief survey, one can see the 'history' of political prudence from the Latin Eustratius to Buridan as a telling example of the creativity of the medieval commentary tradition on the Nicomachean Ethics. The expression prudentia politica, which does not surface as such in the Latin translation of the Nicomachean Ethics becomes, thanks to Eustratius's mediating role, a key concept in medieval Latin commentaries on chapter 6.8. In this process, prudentia politica assumes two different meanings: in a general sense, it designates prudence concerned with the good of the community; in a more specific one, the prudence of the individual as a subject or ordinary citizen in a political community. In the latter case, political prudence is opposed to the legislative prudence attributed especially to the rulers. Commentators discuss the relationship between this kind of prudence and other aspects of the same virtue. In such discussions we perceive also a distinct echo of different political tendencies. Giles of Rome's De regimine principum supports without any difficulty the idea of a clear-cut distinction between the prudence of the ruler and that of the subjects, while other authors are more concerned to safeguard the moral legitimacy of elections.

No commentary that I have examined is ready to accept the idea of a complete separation between individual ethics and politics. The fact itself, however, that even critics of Aquinas's solution use the concept of prudentia politica in its different meanings, shows that the notion of different, albeit related, 'spheres' of ethical activity could gain ground in the medieval reception of the Nicomachean Ethics. 